\title{
Correction to: Risk disclosure and firm operational efficiency
}

\author{
Imen Derouiche ${ }^{1} \cdot$ Riadh Manita $^{2} \cdot$ Anke Muessig $^{1}$
}

๑) Springer Science+Business Media, LLC, part of Springer Nature 2020

\section{Correction to: Annals of Operations Research https://doi.org/10.1007/s10479-020-03520-z}

This erratum is published as funding information was missing in the original article.

Article was funded by the "Fonds National de la Recherche, Luxembourg" (Grant Number C14/IS/8363110/RISK).

Publisher's Note Springer Nature remains neutral with regard to jurisdictional claims in published maps and institutional affiliations.

The original article can be found online at https://doi.org/10.1007/s10479-020-03520-z.

$凶$ Imen Derouiche

imen.derouiche@uni.lu

1 Department of Economics and Management (FDEF), University of Luxembourg, Campus Kirchberg, 6, rue Richard Coudenhove-Kalergi, 1359 Luxembourg City, Luxembourg

2 Neoma Business School, Mont-Saint-Aignan, France 